\title{
KEEFEKTIFAN MODEL PEMBELAJARAN CONCEPT SENTENCE DALAM MENULIS PUISI SISWA KELAS VIII SMP SATAP 48 OKU
}

\author{
Rita Nilawijaya \\ Program Studi Pendidikan Bahasa dan Sastra Indonesia \\ FKIP, Universitas Baturaja \\ Pos-el: nilawijaya.rita@gmail.com
}

\begin{abstract}
Abstrak
Tujuan dalam penelitian ini adalah untuk mendeskripsikan kemampuan siswa kelas VIII SMP SATAP 48 OKU menulis puisi sebelum diterapkan model pembelajaran Concept Sentence, untuk mendeskripsikan kemampuan siswa kelas VIII SMP SATAP 48 OKU menulis puisi setelah diterapkan model pembelajaran Concept Sentence, dan mengetahui efektifitas model pembelajaran Concept Sentence terhadap pembelajaran menulis puisi siswa kelas VIII SMP SATAP 48 OKU. Metode yang digunakan dalam penelitian ini adalah metode eksprimen. Teknik pengumpulan data adalah tes menulis puisi dan teknik analisis data adalah uji t. Berdasarkan hasil penelitian dan pembahasan dapat disimpulkan bahwa hasil belajar siswa kelas VIII SMP SATAP 48 OKU setelah menggunakan model pembelajaran Concept Sentence lebih baik daripada sebelum menggunakan model pembelajaran Concept Sentence. Kata-kata kunci: Keefektifan, concept sentence, menulis puisi.
\end{abstract}

\begin{abstract}
The objectives in this study were to describe the ability of grade VIII students of SMP SATAP 48 OKU to write poetry before applying the Concept Sentence learning model, to describe the ability of grade VIII students of SMP SATAP 48 OKU to write poetry after the Concept Sentence learning model was applied, and know the effectiveness of the Concept Sentence learning model on learning to write poetry for eighth grade students of SMP SATAP 48 OKU. The method used in this research is the experimental method. The data collection technique is the poetry writing test and the data analysis technique is the t test. Based on the results of the research and discussion, it can be concluded that the learning outcomes of the eighth grade students of SMP SATAP 48 OKU after using the Concept Sentence learning model are better than before using the Concept Sentence learning model.

Key words: Effectiveness, concept sentence, writing poetry.
\end{abstract}




\section{PENDAHULUAN}

Pengajaran sastra di sekolah tidak berdiri sendiri sebagai sebuah mata pelajaran yang mandiri, melainkan menjadi bagian mata pelajaran bahasa dan sastra Indonesia. Melalui pengajaran sastra Indonesia di SMP, guru dan masyarakat mengharapkan agar siswa memiliki wawasan yang memadai tentang sastra, bersikap positif terhadap sastra mampu mengembangkan wawasan, kemampuan dan sikap positifnya terhadap sastra serta mampu mengembangkan wawasan, kemampuan, dan sikap positifnya lebih lanjut.

Dalam pelajaran bahasa dan sastra Indonesia, terdapat empat keterampilan yang harus dicapai siswa, yakni keterampilan membaca, menyimak, berbicara dan keterampilan menulis. Keterampilan menulis merupakan kemampuan seseorang untuk membuat karya tulis yang baik dan benar. Salah satu bagian keterampilan menulis yang tercantum dalam kurikulum tingkat satuan pendidikan di Sekolah Menengah Pertama (SMP) adalah menulis puisi. Standar kompetensi menulis puisi pada silabus bahasa Indonesia kelas VIII Semester II SMP berisi, "Mengungkapkan pikiran dan perasaan dalam puisi”.
Menulis puisi merupakan salah satu kompetensi yang harus dikuasai siswa SMP kelas VII dan kelas VIII, tetapi kenyataannya kemampuan siswa menulis puisi masih rendah. Hal ini disebabkan oleh beberapa hambatan. Siswa kurang berminat pada pembelajaran menulis Puisi. Mereka kurang tertarik, merasa kesulitan dalam menuangkan gagasan/ide ke dalam lariklarik puisi, kurang memiliki perbendaharaan kata yang memadai, kurang dapat memilih kata-kata dengan tepat serta kurang memahami bagaimana merangkaikan katakata ke dalam sebuah puisi. Hambatan lain berasal dari guru. Guru kurang dapat menumbuhkan motivasi belajar siswa. Guru kurang mampu menerapkan model pembelajaran yang inovatif dan variatif. Selain itu penilaiannya hanya bertumpu pada aspek pengetahuan dan konsep saja. Model pembelajaran consept sentence merupakan salah satu model pembelajaran yang dapat meningkatkan kompetensi menulis puisi bagi siswa. Model pembelajaran Concept Sentence merupakan salah satu model pembelajaran yang dapat diterapkan di SMP. Model ini menuntut siswa untuk berpikir kreatif. Menurut Huda (2013: 315), model pembelajaran Concept Sentence merupakan strategi pembelajaran yang dilakukan dengan memberikan kartukartu yang berisi beberapa kata kunci kepada siswa, kemudian kata-kata kunci 
tersebut disusun menjadi beberapa kalimat dan dikembangkan menjadi paragraf. Menurut Suprijono (2013: 132), model pembelajaran Concept Sentence merupakan model pembelajaran yang diawali dengan menyampaikan kompetensi, sajian materi, pembentukan kelompok heterogen, penyajian kata kunci sesuai materi bahan ajar, dan penugasan kelompok, prosedur selanjutnya dalam pembelajaran ini adalah mempersentasikan hasil belajar secara bergantian di depan kelas.

Menurut Tarigan (2008: 21), Keterampilan menulis merupakan salah satu aspek keterampilan berbahasa yang penting dalam upaya menuangkan ide. Keterampilan menulis dibutuhkan untuk merekam, meyakinkan, memberitahukan, serta mempengaruhi orang lain. semua tujuan hanya dapat diperoleh apabila disusun dan disampaikan dengan jelas. Keterampilan menulis tidak datang secara otomatis, melainkan didapatkan dari latihan yang intensif.

Model pembelajaran modifikasi Consept Sentence merupakan teknik pembelajaran yang dapat membantu siswa dalam menulis puisi. Dengan teknik ini siswa yang merasa kesulitan dalam menentukan kalimat dapat membuatnya dengan mengembangkan kata kunci yang telah dibuat bersama. Siswa akan menjadi lebih antusias dan bersemangat dalam mengikuti pembelajaran menulis puisi. Dengan model pembelajaran ini siswa merasa bergairah dan lebih tertarik untuk mengikuti pembelajaran kemampuan menulis puisi. Model Pembelajaran yang akan disajikan adalah Model Pembelajaran Concept Sentence dilakukan dengan cara membentuk siswa dengan kelompok heterogen dan membuat kalimat dengan minimal empat kata kunci sesuai materi yang disajikan. Prosedur Model

Pembelajaran Concept Sentence adalah penyampaian kompetensi, sajian materi, membentuk kelompok heterogen, guru menyiapkan kata kunci sesuai materi bahan ajar, tiap kelompok membuat kalimat berdasarkan kata kunci, presentasi.

Huda (2013: 316) mengemukakan langkah-langkah model Concept Sentence meliputi: (1) Guru menyampaikan kompetensi yang akan dicapai. (2) Guru menyampaikan materi terkait dengan pembelajaran secukupnya. (3) Guru membentuk kelompok yang anggotanya kurang lebih 4 orang secara heterogen. (4) Guru menyajikan beberapa puisi bebas sesuai dengan materi yang disajikan. (5) Setiap kelompok diminta untuk membuat beberapa bait puisi bebas dengan menggunakan minimal 4 bait dalam setiap puisi. (6) Hasil diskusi kelompok didiskusikan kembali secara pleno yang 
dipandu oleh guru. (7) Siswa dibantu oleh guru memberikan kesimpulan.

Menurut Suprijono, (2013: 132), tahap-tahap penerapan belajar penemuan adalah menyampaikan tujuan, menyajikan informasi, pembentukan kelompok, penyajian informasi kedua, kemudian tiap kelompok diarahkan membuat beberapa puisi bebas dengan menggunakan beberapa bait yang telah diberikan. Hasil diskusi kelompok didiskusikan kembali secara pleno yang dipandu oleh guru. Terakhir, guru menyimpulkan hasil pembelajaran

Berdasarkan hal di atas, keduanya sama-sama memaparkan adanya beberapa langkah dalam melaksanakan model Concept Sentence yang terfokus pada baitbait yang disusun menjadi sebuah puisi dari pembelajaran tersebut. Dengan ini, peneliti menggunakan langkah-langkah pembelajaran Concept Sentence menurut Huda.

Huda (2013: 317) juga menyatakan bahwa terdapat beberapa kelebihan pembelajaran Concept Sentence. Kelebihan concept sentence tersebut meliputi: meningkatkan semangat belajar siswa, membantu terciptanya suasana belajar yang kondusif, memunculkan kegembiraan dalam belajar, mendorong dan mengembangkan proses berpikir kreatif, mendorong siswa untuk memandang sesuatu dalam pandangan yang berbeda, memunculkan kesadaran untuk berubah menjadi lebih baik, memperkuat kesadaran diri, lebih memahami kata kunci dari materi pokok pelajaran, dan siswa yang lebih pandai mengajari siswa yang kurang pandai. Huda (2013: 317) juga memaparkan kelemahan dari Concept Sentence. Kelemahan model pembelajaran ini yaitu hanya untuk mata pelajaran tertentu dan kecenderungan siswasiswa yang pasif untuk mengambil jawaban dari temannya.

\section{METODE PENELITIAN}

Metode penelitian yang digunakan adalah eksperimen semu (Quasi Experimental Research). Langkah-langkah prosedur penelitian yang dilakukan peneliti adalah sebagai berikut.

1) Memberikan tes pertama $\left(\mathrm{O}_{1}\right)$, yaitu pretest dimana subyek diberi perlakuan menulis puisi sebelum menggunakan model pembelajaran Concept Sentence.

2) Mengadakan perlakuan $\left(X_{1}\right)$, yaitu perlakuan dilakukan sebanyak 4 kali pertemuan meliputi deskripsi kinerja guru dan deskripsi keaktifan siswa dalam pembelajaran menulis puisi dengan menggunakan model pembelajaran Concept Sentence. 
3) Kemudian memberikan tes kedua $\left(\mathrm{O}_{2}\right)$, yaitu posttest dimana subyek diberi perlakuan menulis puisi sesudah menggunakan model pembelajaran

\section{Concept Sentence.}

4) Memberi nilai terhadap $\mathrm{O}_{1}$ dan $\mathrm{O}_{2}$ kemudian membandingkan hasil $\mathrm{O}_{1}$ dan $\mathrm{O}_{2}$ untuk mengetahui perbedaan yang timbul akibat perlakuan yaitu menulis puisi dengan menggunakan model pembelajaran Concept Sentence

5) Menerapkan analisis statistik yang cocok untuk menentukan apakah perbedaan itu signifikan atau tidak.

Populasi dalam penelitian ini adalah seluruh siswa kelas VIII SMP SATAP 48 OKU yang terdiri dari 7 kelas dengan jumlah 238 siswa. Sample yang di gunakan simple random sampling yang dilakukan peneliti adalah kelas VIII.1 berjumlah 32 siswa. Penelitian ini menggunakan teknik pengumpulan data berupa tes menulis puisi. Tes digunakan untuk menjaring informasi tentang hasil belajar siswa. Tes dilakukan baik pada awal pembelajaran (tes awal) maupun pada akhir pembelajaran (tes akhir). Bentuk tes yang digunakan ialah tes untuk kerja berupa meminta siswa menulis puisi dengan tema bebas.

Untuk mengolah data tes menulis puisi bebas, cara menilainya dengan menggunakan model penilaian menulis dengan pembobotan masing-masing unsur sebagai berikut.

Tabel 1. Kriteria Penilaian Kemampuan

\section{Menulis Puisi}

\begin{tabular}{|c|c|c|c|}
\hline No & $\begin{array}{c}\text { Aspek } \\
\text { yang } \\
\text { dinilai } \\
\end{array}$ & Skor & Deskriptor \\
\hline \multirow[t]{5}{*}{1.} & \multirow{5}{*}{$\begin{array}{l}\text { Ketepatan } \\
\text { dalam } \\
\text { menentuka } \\
\text { n judul }\end{array}$} & 5 & $\begin{array}{l}\text { Menentukan judul sangat tepat dan } \\
\text { berhubungan dengan isi puisi } \\
\text { tersebut }\end{array}$ \\
\hline & & 4 & $\begin{array}{l}\text { Menentukan judul sudah tepat tetapi } \\
\text { ada beberapa bait yang tidak } \\
\text { berhubungan dengan isi puisi } \\
\text { tersebut }\end{array}$ \\
\hline & & 3 & $\begin{array}{l}\text { Menentukan judul cukup tepat } \\
\text { namun belum berhubungan dengan } \\
\text { isi puisi tersebut }\end{array}$ \\
\hline & & 2 & $\begin{array}{l}\text { Menentukan judul kurang tepat dan } \\
\text { tidak berhubungan dengan isi puisi } \\
\text { tersebut }\end{array}$ \\
\hline & & 1 & $\begin{array}{l}\text { Menentukan judul tidak tepat } \\
\text { berhubungan dengan isi puisi } \\
\text { tersebut }\end{array}$ \\
\hline \multirow[t]{5}{*}{2.} & \multirow[t]{5}{*}{$\begin{array}{l}\text { Kesesuaian } \\
\text { makna } \\
\text { puisi }\end{array}$} & 5 & $\begin{array}{l}\text { Makna puisinya sangat sesuai dengan } \\
\text { tema puisi, sehingga puisi mudah } \\
\text { dipahami }\end{array}$ \\
\hline & & 4 & $\begin{array}{l}\text { Makna puisinya hampir sesuai } \\
\text { dengan tema puisi, sehingga puisi } \\
\text { mudah dipahami }\end{array}$ \\
\hline & & 3 & $\begin{array}{l}\text { Makna puisinya cukup sesuai tema } \\
\text { puisi, sehingga puisi cukup mudah } \\
\text { dipahami }\end{array}$ \\
\hline & & 2 & $\begin{array}{l}\text { Makna puisinya kurang sesuai } \\
\text { dengan tema puisi, sehingga puisi } \\
\text { sulit dipahami }\end{array}$ \\
\hline & & 1 & $\begin{array}{l}\text { Makna puisinya tidak sesuai dengan } \\
\text { tema puisi, sehingga puisi tidak } \\
\text { mudah dipahami }\end{array}$ \\
\hline \multirow[t]{3}{*}{3.} & \multirow[t]{3}{*}{ Imajinasi } & 5 & $\begin{array}{l}\text { Daya imajinasi yang digunakan } \\
\text { dalam puisi sangat baik dan } \\
\text { menarik }\end{array}$ \\
\hline & & 4 & $\begin{array}{l}\text { Daya imajinasi yang digunakan } \\
\text { dalam puisi hampir baik dan } \\
\text { menarik }\end{array}$ \\
\hline & & 3 & Daya imajinasi yang digunakan \\
\hline
\end{tabular}




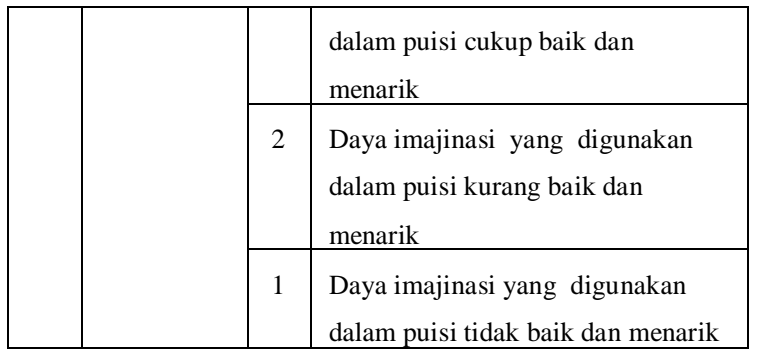

\begin{tabular}{|c|c|c|c|}
\hline \multirow[t]{5}{*}{4.} & \multirow[t]{5}{*}{$\begin{array}{l}\text { Ketepatan } \\
\text { Diksi/ } \\
\text { pilihan } \\
\text { kata }\end{array}$} & 5 & $\begin{array}{l}\text { Pemilihan kata (diksi) dalam puisi } \\
\text { sangat baik dan kata yang dipilih } \\
\text { sangat tepat, serta kata yang } \\
\text { disampaikan sesuai dengan situasi } \\
\text { yang ada dalam puisi }\end{array}$ \\
\hline & & 4 & $\begin{array}{l}\text { Pemilihan kata (diksi) dalam puisi } \\
\text { baik dan kata yang dipilih sangat } \\
\text { tepat, tetapi kata yang disampaikan } \\
\text { belum sesuai dengan situasi yang } \\
\text { ada dalam puisi }\end{array}$ \\
\hline & & 3 & $\begin{array}{l}\text { Pemilihan kata (diksi) dalam cukup } \\
\text { walaupun kata yang dipilih belum } \\
\text { tepat, serta kata yang disampaikan } \\
\text { belum sesuai dengan situasi yang } \\
\text { ada dalam puisi }\end{array}$ \\
\hline & & 2 & $\begin{array}{l}\text { Pemilihan kata (diksi) dalam puisi } \\
\text { kurang dan kata yang dipilih tidak } \\
\text { tepat, serta kata yang disampaikan } \\
\text { tidak sesuai dengan situasi yang ada } \\
\text { dalam puisi }\end{array}$ \\
\hline & & 1 & $\begin{array}{l}\text { Pemilihan kata (diksi) dalam puisi } \\
\text { sangat kurang dan kata yang dipilih } \\
\text { tidak tepat, serta kata yang } \\
\text { disampaikan tidak sesuai dengan } \\
\text { situasi yang ada dalam puisi }\end{array}$ \\
\hline \multirow[t]{5}{*}{5.} & \multirow{5}{*}{$\begin{array}{l}\text { Pendayaan } \\
\text { Pemajasan } \\
\text { dan } \\
\text { Citraan }\end{array}$} & 5 & $\begin{array}{l}\text { Pemajasan dan citraan sudah tepat } \\
\text { karena sudah menggunakan lebih } \\
\text { dari empat majas maupun citraan }\end{array}$ \\
\hline & & 4 & $\begin{array}{l}\text { Pemajasan dan citraan tepat karena } \\
\text { hanya menggunakan tiga majas } \\
\text { maupun citraan }\end{array}$ \\
\hline & & 3 & $\begin{array}{l}\text { Pemajasan dan citraan cukup karena } \\
\text { hanya menggunakan dua majas } \\
\text { maupun citraan }\end{array}$ \\
\hline & & 2 & $\begin{array}{l}\text { Pemajasan dan citraan kurang karena } \\
\text { hanya menggunakan satu majas } \\
\text { maupun citraan }\end{array}$ \\
\hline & & 1 & $\begin{array}{l}\text { Pemajasan dan citraan tidak tepat } \\
\text { karena tidak menggunakan majas } \\
\text { maupun citraan }\end{array}$ \\
\hline
\end{tabular}

(Nurgiyantoro, 2010: 487, yang telah dimodifikasi untuk kepentingan penelitian)

Dalam menganalisis data tes sebagai berikut.

a. Mengumpulkan dan menganalisis tes menulis puisi menggunakan pilihan kata yang tepat dengan model pembelajaran Concept Sentence pada siswa kelas VIII SMP SATAP 48 OKU

b. Memberikan nilai pada hasil menulis puisi yang dibuat oleh siswa kelas VIII SMP SATAP 48 OKU tersebut dengan rumus:

$$
\bar{X}=\frac{X_{1}+X_{2}+X_{3}+X_{4}+X_{5}}{N} \times 100
$$

Keterangan:

$\mathrm{X}=\overline{\mathrm{Ju}}$ mlah skor yang diperoleh

$\mathrm{X}_{1}=$ Ketepatan dalam menentukan judul

$\mathrm{X}_{2}=$ Kesesuaian makna puisi

$\mathrm{X}_{3}=$ Imajinasi

$\mathrm{X}_{4}=$ Ketepatan diksi

$\mathrm{X}_{5}=$ Pendayaan pemajasan dan citraan

$\mathrm{N}=$ Skor maksimal (25)

$100=$ Nilai tetap (Arikunto, 2010: 69).

c. Dari semua nilai siswa yang didapat dicari rata-ratanya dengan menggunakan rumus berikut ini.

$$
\bar{X}=\frac{\sum X}{N}
$$

Keterangan : 
$\bar{X} \quad=$ Nilai rata-rata

$\sum \mathrm{X}=$ Jumlah nilai seluruh siswa

$\mathrm{N}=$ Jumlah sampel penelitian

(Nurgiyantoro, 2010: 219)

d. Menafsirkan nilai untuk melihat efektifitas model pembelajaran Concept Sentence dengan menggunakan rumus uji $\mathrm{t}$ ( $t$ test).

1) $\quad M_{D}=\frac{\Sigma D}{N}$

2) $S D_{D}=\sqrt{\frac{\Sigma D^{2}}{N}-\left(\frac{\Sigma D}{N}\right)^{2}}$

3) $S E_{M D}=\frac{S D_{D}}{\sqrt{N-1}}$

4) $t_{o}=\frac{M_{D}}{S E_{M_{D}}}$

Keterangan:

$\mathrm{T}_{\mathrm{o}} \quad$ : Tes Observasi

SE $\quad$ : Standard Error

$\mathrm{M}_{\mathrm{D}} \quad$ : Mean of Difference

SD : Standard Deviasi (Sudijono, 2011: 324-327).

\section{HASIL DAN PEMBAHASAN}

Penelitian ini dilaksanakan di SMP SATAP 48 OKU dengan subjek penelitian kelas VIII.1 sebanyak 32 orang siswa. Pelaksanaan penelitian dilaksanakan sebanyak 6 kali tatap muka, yaitu 1 kali pretest pada Kamis tanggal 6 Januari 2020, treatment dilaksanakan 4 kali pada tanggal 3, 4,5 dan 6 Januari 2020 serta 1 kali posttest pada tanggal 8 Januari 2020.
Pretest dilaksanakan tanggal 3 Januari 2020 di kelas VIII.1 SMP SATAP 48 OKU. Pretest dilakukan untuk mengukur kemampuan siswa kelas .3 SMP SATAP 48 OKU menulis puisi sebelum diterapkan model pembelajaran Concept Sentence. Kemudian Treatment selama empat kali pertemuan pada 3, 4,5 dan 6 Januari 2020 di kelas yang sama yaitu kelas VIII.1. Treatment ini dilakukan untuk melatih siswa menulis puisi dengan menerapkan model pembelajaran Concept Sentence. Selanjutnya, posttest dilaksanakan pada tanggal 8 Januari 2020 di kelas VIII.1 SMP SATAP 48 OKU. Posttest ini dilakukan untuk mengukur kemampuan siswa kelas VIII SMP SATAP 48 OKU menulis puisi setelah diterapkan model pembelajaran Concept Sentece.

Berdasarkan kriteria pengujian hipotesis bahwa Jika $\mathrm{t}$ hitung $>\mathrm{t}$ tabel pada taraf signifikansi 95\% $(\alpha=0,05)$, maka model pembelajaran Concept Sentence efektif digunakan dalam pembelajaran menulis puisi pada siswa kelas VIII SMP SATAP 48 OKU. Dari perhitungan diketahui bahwa pada taraf signifikansi $5 \%$, diperoleh t tabel 2,04. Karena t hitung telah diperoleh sebesar 9,04, dalam hal ini menunjukkan $\mathrm{t}$ hitung lebih besar dibandingkan dengan t tabel $(9,04>2,04)$. Terbukti bahwa Ha diterima dan Ho ditolak karena $\mathrm{t}$ hitung $>\mathrm{t}$ tabel. Dengan demikian 
bila harga $\mathrm{t}$ hitung lebih kecil atau sama dengan dari harga tabel maka Ho diterima. Harga $t$ hitung adalah harga mutlak, jadi tidak dilihat (+) atau (-) nya. Dengan demikian, hipotesis yang dikemukakan yaitu "Model Pembelajaran Concept Sentence efektif digunakan dalam pembelajaran menulis puisi pada siswa kelas VIII SMP SATAP 48 OKU" terbukti kebenarannya.

\section{Berdasarkan hasil penelitian} terhadap kemampuan siswa kelas VIII SMP SATAP 48 OKU menulis puisi bebas sebelum diterapkan model pembelajaran Concept Sentence diketahui siswa kelas VIII SMP SATAP 48 OKU yang mendapat nilai 80-100 sebanyak 2 orang atau 6,25\%, siswa yang mendapat nilai 66-79 sebanyak 8 orang atau $25 \%$, siswa yang mendapat nilai 56-65 sebanyak 14 orang atau $43,755 \%$, siswa yang mendapat nilai $46-55$ sebanyak 7 orang atau $21,87 \%$, dan siswa yang mendapat nilai 45 ke bawah sebanyak 1 orang atau $3,13 \%$.

Berdasarkan nilai tersebut, nilai siswa kemudian dikelompokkan berdasarkan kategori penilaian seperti dapat dilihat pada tabel 2 berikut.

Tabel 2. Kategori Penilaian Sebelum Menggunakan Model Pembelajaran Concept Sentence

\begin{tabular}{|c|c|c|c|c|}
\hline $\begin{array}{c}\text { No } \\
\cdot\end{array}$ & Nilai & Frekuensi & $\begin{array}{c}\text { Persentase } \\
(\%)\end{array}$ & $\begin{array}{c}\text { Kategori } \\
\text { Penilaian }\end{array}$ \\
\hline 1 & $80-100$ & 2 & 6,25 & $\begin{array}{c}\text { Baik } \\
\text { Sekali }\end{array}$ \\
\hline 2. & $66-79$ & 8 & 25 & Baik \\
\hline 3. & $56-65$ & 14 & 43,75 & Cukup \\
\hline 4. & $46-55$ & 7 & 21,87 & Kurang \\
\hline 5. & $00-45$ & 1 & 3,13 & Gagal \\
\hline & Jumlah & $\mathbf{3 2}$ & $\mathbf{1 0 0}$ & \\
\hline
\end{tabular}

Dari tabel 2 di atas, terlihat siswa yang mampu menulis puisi sebelum menggunakan model pembelajaran Concept Sentence yang mendapat nilai antara 80-100 terdapat 2 orang $(6,25 \%)$ atau dengan kategori penilaian baik sekali. Siswa yang yang mendapat nilai antara 66-79 terdapat 8 orang $(25 \%)$ atau dengan kategori penilaian baik. Siswa yang mendapat nilai antara 5665 terdapat 14 orang $(43,75 \%)$ atau dengan kategori penilaian cukup. Siswa yang mendapat nilai antara 46-55 terdapat 7 orang $(21,87 \%)$ dengan kategori penilaian kurang. Siswa yang mendapat nilai antara 00-45 terdapat 1 orang $(3,13 \%)$ dengan kategori penilaian gagal.

Berdasarkan hasil penelitian terhadap kemampuan siswa kelas VIII SMP SATAP 48 OKU menulis puisi setelah diterapkan model pembelajaran Concept Sentence 
diketahui siswa kelas VIII SMP SATAP 48 OKU yang mendapat nilai 80-100 sebanyak 14 orang atau $43,75 \%$, siswa yang mendapat nilai 66-79 sebanyak 15 orang atau $46,88 \%$, siswa yang mendapat nilai 56-65 sebanyak 3 orang atau 9,38\%, siswa yang mendapat nilai 46-55 dan siswa yang mendapat nilai 45 ke bawah tidak ada atau $0 \%$. Berdasarkan nilai tersebut, nilai siswa kemudian dikelompokkan berdasarkan kategori penilaian seperti dapat dilihat pada tabel 3 berikut.

Tabel 3. Kategori Penilaian Setelah Menggunakan Model Pembelajaran Concept Sentence

\begin{tabular}{|c|c|c|c|c|}
\hline No & Nilai & Frekuensi & Persentase & Kategori \\
$\mathbf{( \% )}$ & Penilaian \\
\hline 1 & $80-100$ & 14 & 43,75 & Baik Sekali \\
\hline 2 & $66-79$ & 15 & 46,88 & Baik \\
\hline 3 & $56-65$ & 3 & 9,38 & Cukup \\
\hline 4 & $46-55$ & - & - & Kurang \\
\hline 5 & $00-45$ & - & - & Gagal \\
\hline & Jumlah & $\mathbf{3 2}$ & $\mathbf{1 0 0}$ & \\
\hline
\end{tabular}

Dari tabel 3 di atas, terlihat siswa yang mampu menulis puisi setelah menggunakan model pembelajaran Concept Sentence yang mendapat nilai antara 80-100 terdapat 14 orang $(43,75 \%)$ atau dengan kategori penilaian baik sekali. Siswa yang yang mendapat nilai antara 66-79 terdapat 15 orang $(46,88 \%)$ atau dengan kategori penilaian baik. Siswa yang mendapat nilai antara 56-65 terdapat 3 orang $(9,38 \%)$ atau dengan kategori penilaian cukup. Siswa yang mendapat nilai antara 46-55 dengan kategori penilaian kurang dan siswa yang mendapat nilai antara 00-45 dengan kategori penilaian gagal tidak ada.

Berdasarkan deskripsi hasil penelitian siswa kelas VIII SMP SATAP 48 OKU bahwa pembelajaran menulis puisi dengan menggunakan model pembelajaran Concept Sentence mengalami peningkatan. Apabila dilihat dari rata-rata skor yang diperoleh pada tes awal adalah 61,06 dan pada tes akhir 76,62 terdapat peningkatan skor yang cukup tinggi sebesar 15,56.

Dari hasil pengujian tes " $\mathrm{t}$ " dapat disimpulkan bahwa ada perbedaan skor ratarata antara tes awal dan tes akhir karena ada efektifitas yang signifikan hal itu dapat diketahui dari pengujian tes " $\mathrm{t}$ " yang menunjukkan bahwa $t_{\text {hitung }}>t_{\text {tabel }}$ atau 9,04 $>$ 2,04 pada taraf signifikansi 5\%. Hal ini menunjukkan bahwa model pembelajaran Concept Sentence efektif dalam pembelajaran menulis puisi pada siswa kelas VIII SMP SATAP 48 OKU.

Nilai mean pada tes awal (pretest) sebesar 61,06 dan hasil mean pada tes akhir 
(posttest) sebesar 76,62. Sehingga, dapat dilihat bahwa hasil tes awal lebih kecil dibandingkan dengan tes akhir, dengan selisih yaitu 15,56. Hal ini menunjukkan bahwa ada peningkatan hasil tes siswa. Sehingga dapat ditarik kesimpulan bahwa model pembelajaran Concept Sentence efektif terhadap pembelajaran menulis puisi pada siswa kelas VIII SMP SATAP 48 OKU.

Keberhasilan peningkatan hasil belajar pada siswa pada saat tes akhir ini, disebabkan pada saat pembelajaran menulis puisi siswa mendapat pembelajaran dengan perlakuan. Perlakuan yang diberikan yaitu model pembelajaran Concept Sentence. Penelitian ini menunjukkan hasil yang baik. Hal ini diketahui dari hasil belajar siswa yang meningkat. Dengan kata lain, pembelajaran menulis puisi bebas dengan menggunakan model pembelajaran Concept Sentence berpengaruh terhadap pembelajaran menulis puisi siswa kelas VIII SMP SATAP 48 OKU.

Pada akhir bahasan ini peneliti menyimpulkan bahwa penelitian ini telah berhasil meningkatkan hasil belajar siswa. Pada saat penelitian dilaksanakan terdapat perbedaan dalam proses pembelajaran dan peningkatan belajar siswa. Perbedaan ini dibuktikan dengan adanya peningkatan hasil belajar yang berbeda antara tes awal dan tes akhir. Dengan adanya perbedaan kemampuan tes awal dan tes akhir ini dapat dikatakan bahwa penggunaan model pembelajaran Concept Sentence berpengaruh terhadap pembelajaran menulis puisi siswa kelas VIII SMP SATAP 48 OKU.

Penerapan model pembelajaran Concept Sentence dalam pembelajaran menulis puisi masih jarang dilakukan. Hal tersebut disebabkan model ini merupakan metode baru. Dengan demikian, agar guru dapat memvariasikan metode pengajaran yang dapat meningkatkan kemampuan siswa dalam menulis puisi.

\section{SIMPULAN}

Dari hasil pengujian tes " $t$ " dapat disimpulkan bahwa ada perbedaan skor ratarata antara tes awal dan tes akhir karena ada efektifitas yang signifikan hal itu dapat diketahui dari pengujian tes " $\mathrm{t}$ " yang menunjukkan bahwa $t_{\text {hitung }}>t_{\text {tabel }}$ atau 9,04 $>2,04$ pada taraf signifikansi 5\%. Hal ini menunjukkan bahwa model pembelajaran Concept Sentence efektif dalam pembelajaran menulis puisi pada siswa kelas VIII SMP SATAP 48 OKU.

\section{DAFTAR PUSTAKA}

Aminuddin. (2011). Pengantar Apresiasi Karya Sastra. Malang: Sinar Baru Algensindo.

Aqib, Zainal. (2013). Model-Model, Media, dan Strategi Pembelajaran 
Kontekstual (Inovatif). Bandung: Yrama Widya.

Arikunto, Suharsimi. (2010). Prosedur Penelitian Suatu Pendekatan Praktik. Jakarta: PT. Rineka Cipta.

Atmaja, Jati. F. (2010). Buku Lengkap Bahasa Indonesia dan Peribahasa. Yogyakarta: Pustaka Widyatama.

Depdiknas. (2008). Model Kurikulum Tingkat Satuan Pendidikan. Jakarta: Badan Standar Nasional Pendidikan.

Djuharie, Otong Setiawan. (2001). Panduan Membuat Karya Tulis. Bandung: Yrama Widya.

Huda, Miftahul. (2013). Model-Model Pembelajaran dan Pembelajaran: IsuIsu Metodis dan Paradigmatis. Yogyakarta: Pustaka Pelajar.

Jabrohim, dkk. (2009). Cara Menulis Kreatif. Yogyakarta: Pustaka Pelajar.

Kosasih. (2012). Dasar-dasar Keterampilan Bersastra. Bandung: Yrama Widya.

Nurgiyantoro, Burhan. (2010). Penilaian Pembelajaran Bahasa dan Sastra. Yogyakarta. BPFE.

Pradopo, Rahmat Djoko. (2009). Pengkajian Puisi. Yogyakarta: Gadjah Mada University Press.

Rusman. (2012). Model-Model Pembelajaran: Mengembangkan Profesionalisme Guru. Jakarta: PT RajaGrafindo Persada.

Sani, Ridwan Abdullah. (2013). Inovasi Pembelajaran. Jakarta: Bumi Aksara.

Sayuti, Suminto A. (2008). Berkenalan dengan Puisi. Yogyakarta: Gama Media.

Sudijono, Anas. (2010). Pengantar Statistik Pendidikan. Jakarta: PT. Raja GraFindo Persada.

Sudijono, Anas. (2011). Pengantar Evaluasi Pendidikan. Jakarta: PT. Rajagrafindo Persada.

Sugiyono. (2010). Metode Penelitian Kuantitatif Kualitatif dan $R$ dan $D$. Bandung: Alfabeta.

Tarigan, Henry Guntur. (2008). Menulis Sebagai Suatu Keterampilan Berbahasa. Bandung: Angkasa. 